\title{
REMEMBERING THE MASSACRE OF CIVILIANS IN ANIOMALAND DURING THE NIGERIAN CIVIL WAR
}

\author{
Odigwe A. Nwaokocha'
}

\section{Introduction}

Many unarmed civilians were killed in Aniomaland during the Nigerian Civil War war fought between July 6, I967, and January I2, I970. The war was a result of the Nigerian federal government's attempt to militarily force the Eastern Region, which had seceded as Biafra, back to Nigeria. The secession was followed by three waves of targeted killings of the Igbo group, mostly from the East in the Northern Region, in May/June, July/August and September/October I966. The Igbo group was the primary target of the attacks (First I970, 3II-334). The Igbo-speaking Anioma people were not part of Biafra but the old Midwest Region on the Nigerian side. They are generally considered as Igbo (Talbot I969; Isichei I976, I6). They were classified as pro-Biafra by federal forces and encountered some unique challenges in the war. The conflict got to them on August 9 I967, when Biafran forces crossed the Niger Bridge, invaded the Midwest and opened a new phase in the war. The armed conflict in Aniomaland was mean, involving the killing of unarmed civilians in many places. This forms the focus of this work.

The work shows that Biafran forces kick-started this terrible episode by invading the Midwest. Historical facts show that their atrocities were lower compared to those of federal forces. There were three waves of civilian killings in Aniomaland during the war. The first involved Biafran killing people of Northern descent and non-Nigerians. The second was the Agbor episode where Ika micro-nationalism, bred by fear of being slaughtered for being Anioma, led some Ika into attacking the Igbo, including the Anioma. The

I Department of History and International Studies, University of Benin, Benin City, Nigeria. E-mail: odigwenwaokocha@gmail.com 
third was the killing of the Anioma people by Nigerian troops in Utagba-Unor, Isheagu, Ogwashi-Uku, Ibusa and Asaba when they overran the area.

Literature on the killings in Aniomaland is paradoxically sad, yet exciting. It is scarce, but packed with facts. No work appeared on the subject until more than two decades after the war, though the facts were known all along to a narrow audience. Emma Okocha's work on the subject is presented in a gusty manner and contains details on the killings in Ogwashi-Uku, Isheagu and particularly Asaba (Okocha 20I2, 47-I62). Stanley I. Okafor's work on the killings in Asaba represents an original eye witness account of what transpired in Asaba. He opines that the killings were not accidental as he witnessed Nigerian soldiers armed with a list from which names were called out and victims summarily executed at the Asaba Police Station (Okafor 2002, 29I). The work of Elizabeth Bird and Ottanelli Frazer on the killings in Asaba is a powerful addition to a field in need of more revelations on what transpired in Asaba in those mad days of October I967. Without being judgmental, the work presented evidence from those present in Asaba when the killings occurred. The work argues that that Nigerian soldiers needlessly killed unarmed fellow countrymen and women for reasons beyond the war (Bird and Ottanelli 20II, I-26). It is noteworthy that these works highlighted above concentrated on the Asaba episode. Similar things happened in other neighboring Anioma towns but have not been highlighted. This work, therefore, attempts to study the killing of unarmed civilians in Aniomaland to expand our knowledge on the subject and help deepen the understanding of the war.

\section{Background to the Nigerian Civil War in Aniomaland}

Many issues contributed to the outbreak of the war. These include the inter-ethnic tensions provoked by the struggle for power among Nigeria's ethnic groups (Bird and Ottanelli 20II, 2-5; Ogunbadejo I979, 85-I00). The immediate sparks which produced the war can be located in the two military coups of I966 and their consequences for a society torn along ethnic and sectarian lines. On the independence from British colonial domination on October $\mathrm{I}^{\text {st }}$, 1960 , Nigeria had many ethnic groups. Among those ethnic nationalities, the Hausa, Igbo and Yoruba were the dominant groups in the three regions (North, East and West). The struggle amongst them for power was laced with some religious flavor that made it highly emotive. National issues were often interpreted along ethno-regional and sectarian divides. This ensured that between I960 and I966 Nigeria stumbled from 
one crisis to another. This, it is believed, led to the January I $5^{\text {th }}$, I966 military coup d'état in which over twenty people were killed. The January coup, led principally by four Igbo and one Yoruba army majors, claimed the lives of some high-ranking civilians and military leaders including Prime-Minister Abubakar Tafawa-Balewa, Ahmadu Bello (Northern Premier); Samuel Akintola (Western Premier) and four high-ranking military officers of Northern and Western extraction. The Federal Finance Minister, Chief Samuel Okotie-Eboh, who hailed from the Midwest was also killed. Major-General J.T.U. Aguiyi-Ironsi (an Eastern Igbo), Nigeria's most senior military officer, emerged as Military Head of State. The fact that the leaders of the coup that produced an Igbo as Head of State were also Igbo, led to insinuations that the coup was an anti-North Igbo plot. This viewpoint created the anti-Igbo riots in Northern towns starting from May 29 $9^{\text {th }}$, 1966. Claiming hundreds of Igbo lives, it set thousands fleeing the North to safety in their ancestral homes in the East and Midwest regions.

Between July $28^{\text {th }}$ and $29^{\text {th }}$, I966, a 'revenge' military coup by Northern military officers took place, killing over forty Igbo military officers, including Ironsi. Lieutenant-Colonel Yakubu Gowon, a Northener, emerged as Military Head of State. The outcome of the two coups, the May I966 anti-Igbo riots in the North and the September I966 killing of the Igbo in the North and Lagos, did much to set Nigeria boiling. As a consequence of the July/August killings within the Nigerian military, an agreement was reached on August $9^{\text {th }}$, I966, to post all military personnel to barracks within their regions to stem the bloodshed. An ad-hoc constitutional conference was also inaugurated on August I2 $2^{\text {th }}$, I966, to chart a future for Nigeria. Seventeen days later, renewed Igbo killings began in the North and parts of the Western Region. Taken together, the killings led to the forced desplacement of over a million Igbo people to the East alone. This soured relations between Ojukwu and Gowon; the government of the East and the federal government and the Igbo and most Nigerian ethnic groups. Citing safety reasons, Ojukwu refused to attend meetings of the Supreme Military Council (SMC) in Lagos. Between January $5^{\text {th }}$ and $6^{\text {th }}$, I967, the SMC met in Aburi, Ghana, and took key decisions on the future of Nigeria. However, the federal government unilaterally reneged on the decisions after federal technocrats warned against their consequences (Kirk-Greene I97I, 344-345). Citing the refusal to implement the Aburi Accord, the Eastern Region issued a series of edicts on Mach $3 \mathrm{I}^{\text {st }}$, I967, seizing federal concerns in the region in order to rise funds to implement some parts of the disowned Aburi agreement (NAI I967, 6). The federal government retaliated by imposing economic sanctions on the East. On May 30 ${ }^{\text {th }}$ I 1967 , the Eastern Region seceded from Nigeria 
as the Republic of Biafra. On July $6^{\text {th }}$, 1967 , Nigerian federal forces attacked Biafra and the Nigerian Civil War started. On August $9^{\text {th }}$, I9 67, Biafran forces invaded Midwestern Nigeria through Asaba in Aniomaland, reaching Ore in the West before being pushed back by federal troops. The last batch of Biafran motorized brigades crossed the Niger Bridge in Asaba into Biafra on the night of October 4, I967. But the war continued in the Aniomaland because Biafran troops continued to infiltrate the area until the war ended. The killings occurred within the struggle for control of Aniomaland between the contending forces.

It is important to understand why both groups killed those they considered enemies anywhere they found them. Essentially, the war was an ethnic issue involving largely the Igbo and Northerners. Other groups joined in, but it remained mostly that. For the Biafrans, Northerners and non-Easterners, except the Anioma, were targets. In fact, seven months before the declaration of Biafra, the government of the East had expelled all non-Easterners, except the Anioma, from the region, claiming inability to guarantee their safety (Ojukwu i969, 46).

For federal troops principally composed of Northerners, the war was a continuation of the massacre of the Igbo in three waves of killings earlier referred to. For them, wherever the Igbo were found, brutal treatment was reserved for them. The truth is that the Anioma loathed federal advance into their territory. They were described as hostile to federal troops (Obasanjo I980, 39). Besides, many Anioma officers formerly of the Nigerian Army escaped to Biafra on the defeat of its forces in the Midwest and joined the Biafran Army. Segments of the Anioma civilian populace were slyly pro-Biafra much to the anger of Nigerian troops (Okpor 20II, Interview). These issues shaped the war and dictated the patterns of killings in Aniomaland.

\section{Biafran Killings of Innocent Civilians in Aniomaland}

With the Biafran occupation of the Midwest between April $9^{\text {th }}$ and September $4^{\text {th }}, 1967$, the non-Igbo residents of Aniomaland faced the threat of death in the hands of revenge-seeking Biafran forces. One of the first acts of the invading Biafran troops on entering Asaba was the attack on the Ogbe Awusa (Hausa Quarter), abode of most of Asaba's northern residents. The quarter's history dates back to between I886 and I900, when Asaba served as headquarters of the Royal Niger Company and Nigeria. Apart from many Northerners in the British Royal Constabulary based in Asaba, numerous Nor- 
thern traders converged there to take advantage of the company's presence. The Northern community in Asaba grew steadily and by 1967 , generations of its members knew Asaba as home, spoke the Igbo language fluently but were still referred to as ndi Awusa (Hausa people). Biafran invaders killed many residents of this community (Okocha 2012, 56-57). Godwin Alabi-Isama believes there is a link between the killings and the Asaba massacre we will encounter shortly (Nation on Saturday 20I2, 20-2I). The Ogbe Awusa killings drove fear into non-Igbo residents of Asaba. The then young Louis Okhuonghae of Edo extraction, a teacher in the town's St. Patrick's College recounted that he escaped through the window of his apartment in Cable Point, Asaba and fled to Benin to avoid death (2006, Interview). An informant resident in Agbor during the Biafran occupation recall that his family smuggled an Esan family in a tipper lorry to safety away from the Biafrans. (Eboka 20I0, Interview). Biafran troops also killed an American Catholic missionary, Brother Roman Wicinsky, who was the Principal of St. Patrick's College, Asaba at Ogwashi-Uku on April I7 ${ }^{\text {th }}$, I968, alleging he was a federal mercenary (Okonji 2006, 25-29). Biafran troops appeared set on revenge on all Northerners they met in Aniomaland. At Ogwashi-Uku (Okocha 2012, I28) and Ubulu-Uku (Ikediashi 2009, Interview), they killed Fulani herdsmen they met. Beyond that, a band of Biafran forces operating in Aniomaland raided the Okapi 3 oil field on May $5^{\text {th }}$, I969, killed ten Italian Agip oil workers and abducted thirty other Italians, West Germans, Lebanese and Nigerians (Okocha 20I2, I29-I3I).

Ordinarily, the murder of unarmed civilians makes no military sense. However, locating the war within the context of the zero-sum-game that shaped it, it was victory against the enemy. Such unwarranted massacres formed a great fulcrum around which the war revolved in Aniomaland, particularly when the tide turned and federal troops took charge. It is impossible to capture the full killings endured by the Anioma in federal hands. A few examples will help illustrate some facts of the chapter and the tragedy of it all for the Anioma.

\section{Agbor: Killing in 'Self-Defense'}

One of the episodes in this regard was the supervised killing of the Igbo in Agbor under the watchful eyes of federal troops of the $2^{\text {nd }}$ Division commanded by Lieutenant Colonel Murtala Mohammed, whose dreaded methods in other parts of the Midwest travelled ahead of him into Aniomaland. Agbor people, whose traditional ruler bore the Igbo title 'Obi', denied 
their Igbo identity (Okocha 20I2, 34). Out of fear and in defense of a new emergent identity, indigenes of Agbor joined soldiers of the $2^{\text {nd }}$ Division, whose Commander was installed as Odogwu of Owa by the smart Obi of Owa, to fish out Igbo, including Anioma people, for killing. They killed their kind in 'self-defense'. While some Ika have denied this, three independent sources confirmed it (Anonymous Informant 20IO, Interview; Okoh 20II, Interview; Okonmah 2009, Interview). The Agbor killings were perhaps the worst episodes of the war in Aniomaland, given the fact that an Anioma group joined in murdering their fellow people.

Another area of killing during the federal onslaught on Aniomaland was Utagba-Unor. There, the Okpala-Uku and his chiefs were killed in I967 in his house where they had gathered for a meeting with federal troops. The only survivor was the Okpala-Uku-in Council's Secretary. Federal troops claimed they assisted Biafrans to attack their stations around the community (Okpor 20II, Interview). However, the attack pales into insignificance when compared with the bigger tragedy that unfolded at Isheagu in Ig68.

\section{The Tragedy of Isheagu}

Isheagu was attacked on May $2^{\text {nd }}$, I968, for becoming a threat to the federal army. By I968, Isheagu had emerged as a major market supplying Biafra with needed goods across the Niger. Secondly, the bushes behind Isheagu held many Biafran soldiers, thus posing a threat to the Nigerian IO2 Battalion stationed there. Isheagu people were accused of collusion in Biafran attacks on federal positions in the area. To get a foothold on Aniomaland and possibly recapture parts of the Midwest, Biafran forces landed in the largely uncharted area of the western bank of the Niger to the south of Asaba in early ig68 (Nwabueze 20II, Interview). This Biafran presence constantly harassed federal troops in the locale. Just days before the attack, a Biafran bomb blasted a federal squad around the nearby Nsukwa junction (Unoshai 2009, Interview). Unable to ward-off attacks from that angle, federal forces accused the people of colluding with Biafrans and vented their frustrations on them. It is estimated that about three hundred people, including the town's traditional ruler, Obi John Izechinor Onyema, were killed. The Obi was reportedly buried alive (Okocha 20I2, I04).

The motives for the attack remain unknown. An eyewitness account from Chief Pius Unoshai revealed that when federal troops arrived Isheagu in late 1967 , people ran away to their farms, given the well-known notoriety 
of federal troops that went ahead of them to Isheagu. On the encouragement of federal troops, many returned to town. Shortly after that, rumors began about the intention of federal forces to attack Isheagu for supporting Biafran attacks on them. At the spread of these rumors, a particular Yoruba officer friend, Liutenant Paulinus, informed him of the impending attack and advised him to re-locate. He told his people, who doubted him. He alleged that some federal troops friendly with the town's people, including Paulinus, were transferred before the arrival of the murderous troops. They arrived May I ${ }^{\text {st }}$, I968, and attacked on the next day under the leadership of Captain Patrick Idahosa. An Ogwashi-Uku based veteran officer of Isheagu origin, Mr. Ezeogor, who had running battles with the attitude of the federal army in the area, had informed his people about the dreadful plans of the federal soldiers towards them. He was locked up at the battalion's headquarters in Isheagu for spreading 'malicious' rumors. When they eventually descended on the town, he was brought out and executed. As the killings went on, some energetic Isheagu young men were reserved to dig huge graves for mass burials. Virtually all the houses in the town were destroyed and those with zinc roofing sheets had them removed and taken away. Most who survived the dawn attack again emptied into the bush. It will appear that even with the tragic turn of events in the community, the occupying federal forces were dissatisfied with the general level of destruction visited on the town. Seeing that many Isheagu residents escaped, federal troops invaded the hide-outs around the town and killed many people in their farm hide-outs. One Joseph Osaji was be-headed by a federal soldier named Dan Beki in the bush (Unoshai, Interview). Many who sneaked into town from the bush to pick up needed items were shot by federal forces (Okocha 20I2, I04).

The attack wiped out the old Isheagu. On a visit to the town no house sighted appears older than I970. A source at Isheagu says an Ewulu man and his pregnant wife trekking to Isheagu after the killings were accused of being Biafran spies and shot dead by federal troops (Ofili 2009, Interview). The nature and consequences of the Isheagu attack was simply too vicious in its larger ramifications to have been just aimed at giving the federal side an advantage in the struggle with Biafra for Aniomaland. This angle becomes important against the background that the attack was not waged by Northerners alone. Unoshai has insisted that federal troops of Ika, Urohobo, Edo, and Ijaw origins were actively involved (2009, Interview). It is difficult not to conclude that some of the killings in Aniomaland were a continuation of the earlier September 1967, killings in other parts of the Midwest against the Anioma. An ex-Nigerian soldier of Edo extraction who fought in Aniomaland during the war justifed the attacks on the Anioma by arguing it was in retalia- 
tion for the Igbo invasion of Benin, which he alleged the Anioma supported actively. He described the invasion of Benin in sacrilegious terms and said those who aided it "[...] had to pay anyhow" (Osarenkhoe 2007, Interview).

\section{Disaster at Ogwashi-Uku}

Earlier on, Ogwashi-uku had witnessed some senseless slaughter of civilians with very harsh consequences for the Onukwu family. Federal troops had raced to Ogwashi-Uku from Umunede without any opposition until they encountered Biafran resistance at Ogwashi-Uku. After some skirmishes, federal forces resorted to what became their customary practice in Aniomaland by turning on unarmed civilians. This tactic of recourse to the area of least resistance left permanent marks on the history of the Onukwu family. Before that, a background to the tragedy that befell the Onukwus is necessary.

The military situation in some sections of Aniomaland when federal troops entered Ogwashi-Uku from the western Ubulu-Uku end was unsettled. Retreating Biafran forces camped at Isa on Ogwashi-Uku's immediate west. On the approach of federal troops, some of them dispersed into the bush and regrouped. Others continued their eastward retreat. Desperate Biafran forces, needing to avoid being cut-off by advancing federal forces from the Benin and Warri ends, were also still evacuating to the East from the old Aboh Division on Ogwashi-Uku's southern flank and necessarily passed through Ogwashi-Uku. The unimpeded nature of federal advance from Umunede meant Biafrans troops were still around Ogwashi-Uku. That was the situation when federal forces entered the town. They met a near empty town as many inhabitants had fled (Ilechie 20II, Interview). While in the town, federal troops clashed with a fragment of Biafran forces, suffering some casualties, including a commander. The decisive battle occurred between the Post Office and Government Primary School. Federal troops triumphed with the Biafrans retreating eastward to Ibusa. The battle brought the unlucky Onukwu family, whose house was in the vicinity, into the picture.

Added to the previous day's losses, the second clash cost the federal side some casualties. Suspecting a conspiracy between the people and the Biafrans, federal troops turned on the Onukwu family. Babatunde Onukwu and five of his brothers (Iweadizia, Ndufodu, Anisimbili, Ogbogu and Augustine) were lined up and killed by angry federal soldiers before their mother, Mrs. Onwuegbuzie Onukwu. Unable to bear the ordeal, she lost her mind; 
ran mad and never recovered until she died in the late I990's (Udegbue 20II, Interview). The Onukwu family tragedy demonstrated the callousness with which federal troops treated the Anioma during the war. A dreadful price was extract from the Ogwashi-Uku community for belonging to the Anioma community. For the Anioma, who the federal forces identified with Biafra, it was one more chapter of a bloody book on their travails in a conflict that put them right in the middle of hell.

The Onukwu family tragedy was not the only incidence of unarmed civilians being targeted for brutal treatment in Ogwashi-Uku. The story of Afamefuna Elue is instructive for the cold shivers federal presence sent into the spines of even the seemingly powerful among the Anioma. This can be gleaned from the response to a question by the Obi of Ogwashi-Uku on the death of Afamefuna Elue. As Secretary of the Ogwashi-Uku Development Union, Elue was a lading light in the town. Accused of being pro-Biafra, he was abducted by federal forces and his corpse dumped in a rubber plantation. Years later, his son asked the Obi why he could not save his father. The Obi's response was: "When they went to Isheagu, they buried the Chief alive. I'm sorry about your father. I was not just ready for that kind of death" (Okocha 2012, I04).

The response shows the Anioma threaded with caution in their dealings with federal troops who sparked at the slightest provocation. The Anioma fear of federal troops was founded on their activities in the area. This can help us understand the destruction of the bridge across the Oboshi stream (which connected Ogwashi-Uku and Ibusa) by some Ibusa youths and troops of Biafra's retreating $\mathrm{I}^{\text {th }}$ Battalion to prevent federal troops from extending the havoc visited on Ogwashi-Uku to Ibusa (Ikpo 2008, Interview).

The destruction of the bridge prevented federal troops from entering Ibusa from the Ogwashi-Uku end. They turned back to Ogwashi-Uku at the broken bridge and connected Asaba through Azagba-Ogwashi, entering Ibusa from the Asaba end. Before they reversed at the broken Oboshi bridge, the town's ruling elite led by its oldest man, Obi Mordi (the Diokpa of Ibusa, who was over a hundred then) waded through the Oboshi stream to meet and welcome federal troops at the Ogwashi-Uku end of the broken bridge. Apart from Obi Mordi, the welcome party included he charming Omu Igbuzo, Madam Nwaoboshi, and other prominent people in the town. They waded through the stream to meet the soldiers at the other end. They probably left an indelible impression. On entering Ibusa, federal troops initially did not harass, torture or shoot anyone (Okonji 2006, Interview). 
Despite the fact that individuals were not targeted for shooting, the people heard a lot. Ibusa has Asaba to the east and Ogwashi-Uku to the west. Federal troops had visited both places, killing and brutalizing many. So, when they entered the town many fled. Some later returned as federal troops 'disappointed' them. Meanwhile, unknown to federal troops, the bushes around Ibusa became major hub of opposition to federal presence. The Biafrans, still around deep in the forests of the town's Uzor Umuze, seized the opportunity of the population in hiding to recruit massively into her ranks. For a time, all was quiet. The uneasy calm snapped on Easter Monday (April I6) I968 when a Biafran squad slipped in and attacked the St Michael's Primary School camp of federal troops, inflicting some casualties. This created a new equation in the relationship between the Ibusa people and federal troops. Federal troops attacked and killed about twenty people in retaliation (Ikpo 2008, Interview). It took the intervention of the town's catholic parish priest, John Osia and the Principal of St. Thomas' College, the then Rev. Fr Anthony Gbuji, to stop the carnage (Osia 20I2, Interview). Most inhabitants of the town fled into the bush. Only the infirm and the very determined remained. Majority of the latter group were relocated to the refugee camp at St. Patrick's College, Asaba by federal troops as Biafran infiltration continued. Edgy federal troops brutalized or shot anyone who sauntered into town from the bush, classifying them as Biafran spies.

Federal troops were quite cruel towards the Anioma. Three of their spiteful activities around Ibusa need recollecting. While the people of Umudi were escaping into the bush for safety, they relocated a blind old woman, Martha Emeshie, from her house to the outskirts of the town. Family members visited her occasionally to assist her as she lived alone in her emergency shelter. One day, federal troops poured fuel on her make-shift thatch hut and roasted her to death (Agokei 20II, Interview). Another incidence of senseless killing involved two senior bankers at Barclays Bank, Asaba. Joseph Onyemem and Emmanuel Anuchi-Ogbolu, were Branch Manager and Accountant, respectively. According to reports, shortly before the Easter of I968, three soldiers stormed the bank and demanded for the keys to the bank's safe from the Accountant. His refusal earned him abduction alongside the Manager. Their corpses were later found on the Ibusa-Asaba road (Okocha 2OI2, IO3-IO4). An Ogbolu family believes the dastardly act was perpetrated by a Captain Patrick Idahosa-led squad of the Nigerian Army (Ogbolu 20II, Interview). Possibly due to the power of Barclays Bank in world financial circles, pressure mounted on federal authorities to act. The alleged perpetrators were court marshalled and executed (Okocha 2OI2, IO3-IO4). On Captain Idahosa, nothing was heard of the crime from the Nigerian Army. 


\section{The Catastrophe in Asaba}

What ranks as the greatest mass slaughter of the war in Aniomaland took place at Asaba. The extent of civilian massacres there involving troops of $2^{\text {nd }}$ Division will always remain difficult to put into words. In intensity, scope and the sheer quantum of the crudity, all the other killings in Aniomaland will, even when put together, rank below what engulfed Asaba in early October i967. The Asaba episode can be understood within the context of the fight for Asba between the contending forces. Federal troops had entered Asaba through the Okpanam end. That was not, however, until they overcame a Biafran resistance at Okwute-Ugbor. The battle for Asaba was a series of pitched battles. Two of them stand out. The first was the battle of Okwute-Ugbor, a few kilometers from Asaba. The second was the battle for St. Patrick's College. Retreating Biafran troops from other parts of the Midwest had built up a strong defensive position at Okwute-Ugbor and waited for advancing federal troops.

Asaba was the last place in the Midwest before the Niger and Onitsha, which federal forces coveted. It was therefore defended by a Biafran brigade commanded by an Anioma son, Col Joe Achuzia. He had set up an operations headquarters in Asaba days before the arrival of federal troops. He was Acting Biafran Midwest Divisional Commander. After the withdrawal from Umunede, he had crossed the Niger to Enugu on October $2^{\text {nd }}$, I967, to seek audience with Ojukwu on the Midwest situation, requesting that an officer of Anioma origin be appointed Divisional Commander for the Midwest operations. Col Nwawo who was appointed to resume duties immediately could not arrive Asaba before federal troops arrived Asaba. It became Achuzia's lot to defend Asaba against federal assault. Biafran troops had dug in at Okwute-Ugbor and St. Patrick's College. At the battle of Okwute-Ugbor a top federal commander, Col Godwin Alley was shot on the chest and evacuated from the front, feared dead. Biafran troops recoiled to their St. Patrick's College defensive positon. The superior push of federal troops made continued defense of that position untenable. Biafran troops then withdrew from their last dug in position in Aniomaland (Achuzia I993, 33-35). The fierceness of the battle for Asaba did not temper itself even inside the town. The bullet marks on the Asaba water reservoir, still visible to the naked eye today, tells a story of how bullets flew all over. It ended in defeat for Biafran forces, who retreated across the Niger to Onitsha in the evening of October $4^{\text {th }}$, I967. The following day, the Niger Bridge was blown up by the Biafran Army. 
No one knows exactly why federal troops killed civilians in Asaba the way they did. We know, however, that Asaba was the only place in Aniomaland where federal troops were stiffly resisted and engaged in battles in real war situations. There is a suspicion that it was the battles in Asaba that ended in the killings. Federal soldiers were known to have complained that Asaba people colluded with Biafran troops (Uti 20I2, Interview). Federal troops fought their real battles in Aniomaland in Asaba. Their casualties were high and thought to include Col Alley. It is possible that the cumulative anger arising from these drove federal forces into visiting their frustrations on scapegoats they held responsible for their hitches. We can also classify the Asaba episode as a continuation of federal army's anti-Igbo tendencies. They demonstrated their readiness to kill the Anioma population while hanging on to flimsy excuse of provocation in Utagba-Unor and Ogwahsi-Uku. Asaba was just another Anioma town, so the pattern was repeated.

It has been established that between October $5^{\text {th }}$ and $7^{\text {th }}$, I967, over four hundred unarmed civilians were killed by Nigerian soldiers in Asaba. Emma Okocha has drawn up a list of four hundred and seventy-two persons as having been killed in bizzare circumstances in in Asaba (Okocha 20I2, 89-94). Bird and Otanelli put the number at about a thousand (Bird and Otanelli 20II, 2). Olusegun Obasanjo, one of the top federal commanders in the war has tried to make light of the tragic Asaba episode by claiming that the massacre was:

[...] an event involving some fifty civilians ... in Asaba without the knowledge of or approval of senior or superior officers. Troops of 8I Brigade... carried away for execution those civilians whom they suspected to be spying on them on behalf of the rebels after ... federal troops had suffered heavy casualties from surprise attacks by the rebels (Obasanjo I980, 39-4I).

The claim does not add up. That more than four hundred people were spying for Biafra in Asaba is incredible. The nature of the killings cannot possibly justify this charge. The federal troops appeared prejudiced against the people and openly threatened Asaba residents with death. A survivor of the Asaba killings recalled how a Nigerian soldier declared his hatred for all Igbo people, who “... must die" (Bird and Otanelli 20II, I6). The killings seem to have been inspired by hate. The facts of the killings seem to bear this out. In one instance, people were invited to pre-arranged welcome ceremonies for federal forces. In the process of the welcome, men were separated from women and shot. In some other cases, federal troops visited family houses 
to carry out killings. At other times, people were gathered at the Police post, names called out from a list and people shot. Most of those killed were buried in mass graves, the biggest of which is at Ogbeosowe. The way the killings went and the caliber of some the victims suggest that some of them were targeted killings. The list of the Asaba dead included Mr Sylvester Ugoh, a retiree and supposedly Anioma's wealthiest personality of the era. L.G. Gwam, former Director of the National Archives, Ibadan was also killed and his historical documents destroyed or carted away. Killed also were the Resident Doctor of the Asaba General Hospital, Dr. Eugene Akwule and one of Nigeria's leading athletes of that era, Sydney Asiodu.

The killers in Asaba were reportedly armed with lists of who must die. P.I.G. Onyebobi's name was probably on such a list. He was an Administrative Officer in the midwest civil service before the war. He was apparently targeted in Asaba when he was attacked in his family house, shot and left for dead. He survived the attack and thereafter escaped to Achalla-Ibusa, where he received initial treatment. In order to deter the soldiers from coming back for him, his family organized a phantom burial for him, complete with a 'grave'. This they showed to federal troops who came back to ensure that he died. His experience of the whole episode, in his words, is very instructive:

In October 1967, federal troops entered Asaba.... On October 7, people carried dancing groups to receive them at Ogbeosowe. They were surrounded and mowed down....Most people who heard what happened ran away to surrounding villages. I didn't run..... On October 8, I had my own baptism. I was sitting with an uncle and some relations in a house near my father's house and we were chatting when we suddenly saw some soldiers walk past at about 3 p.m. They were four of them. Their leader, I guess a lieutenant asked us if there were women and children here. I answered saying no. Then, he just said, 'kill them'. I thought it was a joke but a soldier came in an opened fire point blank at me. I was surprised that I was still conscious when I opened my eyes.... I tried to be calm, but it was a serious matter. I just kept calm thinking that was the end and that they will go away but they didn't. I think the same officer came back and started touching us one by one. When he touched me, he said 'this one has not died, come and shoot him again.' I heard another shot but surprisingly I was still not dead. Then he checked again and said that I was dead and that they should go (The Guardian on Sunday 2013, 22).

Professor Stanley Okafor, who was in Asaba then and accompanied his father to the Asaba Police Station avers that names were called out from a list. The people who responded were taken behind the building and executed. His father, a senior civil servant in the midwest before the war, was killed but 
not at the Police Station by federal troops and his stolen car later recovered in Lagos from an army officer (Okafor 2002, 293-300).

A deeper perspective of the Asaba tragedy comes from survivors who lived through it and still nurse the emotional scars. One of them said that with the way the killings went she taught the world had ended (Onianwa 20I0, Interview). The Asaba episode represented the activities of a hate-filled group. It was a nightmarish experience for the people. It involved all sorts of evil. According to Stanley Okafor: "The crimes and human rights abuses perpetrated by the federal troops in Asaba are unimaginable. They murdered, they stole, they looted, they raped" (Okafor 2002, 297). An informant who was in Asaba during the killings said the following:

The Asaba story can only be told by people from the angle of what they saw. The full story will never be known. I knew so many of the dead. All I and women like me did was to encourage our sons, husbands and brothers to stay in hiding while we monitored events and helped bury the dead (Okonkwo 2009, Interview).

The President of Asaba Development Association, Dr. Louis Odogwu, said Asaba people will never forget their war-time experiences. A partnership has been forged with the University of South Florida to establish a holocaust museum for the Asaba dead (Odogwu 20I2, Interview). A memorial has also been erected at Ogbeosowe to honor the dead.

The deep pain of the killings by federal troops in Aniomaland lingers for those who lost dear ones. It has been dismissed as inconsequential and publicly denied when historical facts state otherwise. For instance, I.B.M. Haruna, successor to Murtala Mohammed as $2^{\text {nd }}$ Division commander, coldly told the Oputa Panel he owed no apologies for the conduct of troops that eventually came under his command (Ojeifo and Ughegbe 20I3). Olusegun Obasanjo, a leading federal commander in the war and later Nigeria's Military Head of State (I976-I979) and civilian President (I999-2007) commented on Asaba calamity in a condescending manner, dismissing it with the claim that federal troops killed fifty people who were spying for Biafra in an operation that was not approved by senior officers (Obasanjo I980, 39-40). He did not say how many of the killers were court-marshalled for an illegal operation. The puzzling fact is the same Obasanjo visited Asaba on October $13^{\text {th }}$, 1967 (Obasanjo I980, 47). The killings started on October $6^{\text {th }}$, seven days before his visit. Over four hundred people were killed in Asaba by the Nigerian Army. It is amazing that the victims including very senior citizens, children and women were part of the Biafran spying ring. 
It is a historical fact that Nigeria's war-time Head of State, Yakubu Gowon, has apologized for the conduct of federal troops in Asaba. Part of it reads:

[...]accept my apologies on behalf of the Federal Military Government on the activities of the soldiers in Asaba during the civil war ... I'm sorry for what happened especially to those people who lost families. It was not out of malice but an accident of war.... I hope Asaba people will accept this apology even if it is belated.... I felt very touched.... being the one in charge at that time. Certainly, it is not something I would have approved of whatsoever. I was made ignorant of it [...]. (Aneke 20I3).

Gowon's apology appears designed to mislead and conceal. Extant evidence smothers his claim of being unaware of the killings at the time. His war-time Commissioner for Information, Chief Anthony Enahoro, revealed that Gowon knew more than his apology contained. According to him at a reconciliatory meeting with some Igbo in New Jersey, U.S.A. in I998:

[...] I was the one that stopped late General Murtala Mohammed from further massacre of innocent children and mothers. At a point when Britain refused to sell further arms to Nigeria because they had ample evidence from the Red Cross of the federal forces killing innocent civilians, I confronted Gowon with the fact and that the only way I can get Britain through my contact with their High Commission to resume supply of weapons to Nigeria was that Murtala had to leave the war sector. Either Mohammed leaves or I will leave his cabinet. Gowon told me he was willing to call a meeting on the condition I will be the one to confront Murtala. If there was anybody that Gowon feared so much it was Murtala Mohammed. At the meeting of the Federal Executive Council, I confronted Mohammed with elaborate evidence complete with photographs. He was livid. He could not refute them, so he resorted to calling me all sorts of names.... I was instrumental to his withdrawal from that sector and subsequent appointment as a minister (Aneke 20I3).

Given what Gowon knew, his claim of ignorance is suspect and his apology meant to cover up the crime of mass murder known to him.

The awful treatment meted out to the Asaba people about sums up what the Anioma suffered in a war termed 'civil'. With war-time atrocities in Asaba and Aniomaland in general, it is difficult not to speak of Nigeria and its army in roguish terms. Despite Gowon's apology, the scars remain and the painful memories endure. It was an appalling act of crass callousness 
that wrecked many dreams and destroyed scores of families. It wiped out many men and created many female head of households. Those ignorant of what occurred in Asaba spoke of Asaba women in derisive terms (Onianwa 20I0, Interview). It made the gloom even darker.

The war probably hit its lowest point in Aniomaland. Beyond describing the Asaba killings in genocidal terms, Senator Uche Chukwumerije has stated that: "if the civil war was one black spot in the history of Nigeria and if blackness has degrees ... Asaba is the blackest spot in Nigerian history" (Vanguard 2012, I3). What the Nigerian Army did in Aniomaland was simply abominable. In the hands of the federal army, the Anioma were defenseless as they were neither Biafrans nor Nigerians then. The lacunae was exploited by federal troops with impunity. The war condemned them to a terrible fate in the hands a revenge-seeking army. They were simply abandoned to their fate. Even an international observer team that toured $2^{\text {nd }}$ Division's area of operation between September $24^{\text {th }}$ and November $23^{\text {rd }}$, I968, glossed over massive evidence of atrocious acts perpetrated by federal troops in Aniomaland and gave the Nigerian Army a clean bill of conduct (NAI I968). In denying the attempted systematic destruction of sections of the Anioma community, the world simply told the Anioma that history is always written by the winner. Their disastrous experience continues to live with them. Perhaps the totality of the Anioma experience in the hands of the Nigerian state and its army can be summed up in the words of Professor Wole Soyinka. Referring to them as midwest Ibo, he captured their war-time dilemma in the following words:

The most vulnerable Nigerians at that time were the Midwest Ibos, especially ever since the Midwest invasion. They had been hounded, hunted and killed since that event and were considered greater security risks than the real Ibos themselves...Asaba Ibos required ten positive acts of loyalty to one of the rest of the nation to prove themselves human beings (Soyinka 1990, 76).

\section{Conclusion}

The entry of the civil war into Aniomaland took the fight to the people in their home. As this work has shown, there were two sides to the killing of unarmed civilians during the Nigerian Civil War in Aniomaland. One involved the Biafrans, while the other was perpetrated by federal troops. The last was more pervasive. Though the Anioma tried to be ambivalent in their 
choice, they were stereotyped and suffered massacres as a consequence. The tragedy of the Anioma people will be better appreciated when some issues are taken into consideration. The attacks on the Igbo, including the Anioma happened in the North in May, July/August and September/October, Ig66. Anioma elite in the North ran home to Aniomaland and other parts of the Midwest before the war. Part of what the war brought to the table for Anioma were attacks on them in Benin City and other Midwestern towns. Again, they ran home to their ancestral towns. The invasion of their towns and villages by federal troops exposed them to further attacks and they were buffeted upon with hardly anywhere to run to. Even in their villages, they became displaced and went into hiding. Those of them who encountered federal troops were killed. This explains why the Anioma lost some of their very best in the war. Utagba-Unor, Isheagu, Ogwashi-Uku, Agbor, Ibusa, Asaba and other points where the innocent Anioma blood was shed are symptomatic of what is often denied in Nigerian official circles: that the civil war was an ethnic event. It was a deep manifestation of a system that failed and found scapegoats among its fold to blame and to massacre as culprits. With the nature of the killings in Aniomaland by federal troops, it is difficult to escape the conclusion that there were indiscriminate killing intentions . It is easy to see that the Anioma were targeted for destruction. Murtala Muhammed (seen as a national hero in Nigeria), the Commander of the $2^{\text {nd }}$ Division of the Nigerian Army must share a large bulk of the blame for the blatant massacre of the Anioma under his watch.

On the whole, combatants in the war in Aniomaland gloried in killing defenseless civilians. Their actions exposes the rotten possibilities of ethnoregional conflicts and the larger tragic nature of war. Wars make us lose our humanity. But it should never be so. The massacre of defenseless civilians in Aniomaland in the course of the Nigerian Civil War continues to reverberate today, perhaps tomorrow and possibly forever.

\section{REFERENCES}

\section{Interviews}

Agokei, Theresa Nwafulueze (Born 1954), School Teacher, Lagos, June I4, 2011.

Aniedue, Fidelis (Born I954), Businessman, Ibusa, December 26, 2010.

Anonymous Informant (Born I935), Ex-Soldier, Boji-Boji Owa, November I7, 2010. 
Eboka, Chuks (Born I950), University Academic, Benin City, April 3, 20 IO. Echenim, Kester (Born I948), University Academic, Benin City, September 27, 2009.

Ikediashi, Michael (Born I929), Retired Public Servant, Ubulu-Uku, September 24, 2009.

Ikpo, Nosike (Born I930), Ex-Senator and Traditional Chief, Ibusa, January 6, 2008.

Ilechie, Suzzy Mgboude(Born I9ı), Community Leader, Ogwashi-Uku, April 20, 20II

Nwabueze, David (Born I938), Businessman, Utagba-Ogbe (Kwale), August 3, 2011 .

Odogwu, Louis (Born I937), Medical Practitioner, Benin City, November I2, $2 \mathrm{OI} 2$.

Ofili, Alice (Born I940) Trader, Isheagu, December 29, 2009.

Ogbolu, Larry (Born I953), Businessman, Benin City, February I4, 20 II.

Okhuonghae, Louis (Born I944), Medical Practitioner, Benin City, March 9, 2006.

Okoh, Regina (Born I932), Trader, Umunede, July 20 II.

Okonmah, Beatrice (Born I932), Seamstress, Benin City, September 28, 2009.

Okpor, Paul Chidi (Born I938), Utagba-Ogbe (Kwale), August 3, 20 II.

Okonji, Edward (Borni947), School Teacher, Ibusa, June 24, 2006.

Okonkwo, Ogbeianu (Born I929), Community Leader, Asaba, December 29, 2009.

Osarenkhoe, Ibizugbe (Born I936), Ex-Soldier, Benin City, March 30, 2007. Osia, (Born I940), Priest and Rtd. University Academic, Lagos, March 22, 2012.

Otuya, Paul (Born I935), Community Leader, Utagba-Ogbe (Kwale), August 3, 2011

Onianwa, Egomdi (Born I928), Trader, Asaba, Io October 2010.

Onianwa, Ifeanyi (Born I938), Retired Public Servant, Asaba, May 7, 20 Iо.

Udegbue, Okafor (Born I948), Community Leader, Ogwashi-Uku, April 2I, 2OII.

Unoshai, Pius (Born 1934), Community Leader, Isheagu, December 27, 2009 . 
Uti, Evans (Born I942), Businessman, Asaba, March I5, 2012.

Uzoronicha, John (Born I952), Ex-Soldier and University Academic, Benin City, August 26, 20II.

\section{Books, Articles and Others}

Achuzia,J.O.G. I993. Requiem Biafra. Lagos, Nigeria: Steel Equip Ltd.

Akpan, N.U. I976. The Struggle for Secession Akpan: A Personal Account of the Nigerian Civil War. London: Frank Cass.

Aneke, Nnaemeka Luke. 2003. “Gowon's Apology to the Igbo Lacks Sincerity". http://www.nigeriamasterweb.com.

Bird, Elizabeth S. and Fraser Ottanelli. 2oII. "The History and Legacy of the Asaba, Nigeria Massacres.", African Studies Review 54, no. 3: I-26.

Eastern Nigeria Ministry of Information.I966. Nigerian Pogrom: The Organized Massacre of Eastern Nigerians. Crisis Series 3. Enugu, Nigeria: Government Printer.

First, Ruth. 1970. The Barrel of a Gun: Political Power in Africa and Coup D'état. Harmondsworth: Penguin Books.

Isichei, Elizabeth.I976. A History of the Igbo People. London: Macmillan Press. Kirk-Greene, A.H.M. I971. Crisis and Conflict in Nigeria: A Documentary Sourcebook, 1966-1971, Vol. I. London: Oxford University Press.

Nation on Saturday (Nigeria). 2012. "Chinua Achebe Lied." November 24.

National Archives Ibadan (NAI). I968. File CWC I/4II. "No Genocide: Final Report of the Observer Team to Nigeria." Lagos, Nigeria: Federal Ministry of Information.

Obasanjo, Olusegun. I980. My Command: An Account of the Nigerian Civil War. 1967-1970 Ibadan, Nigeria: Heinemann.

Ogunbadejo, Oye. I979. "Conflict Images: Colonial Legacy, Ethnicity and Corruption in Nigerian Politics". Utafiti, 4, no. I (July): 85-100.

Ogwuda, Austin. 2002. "Gowon Faults Setting Up of Oputa Panel”. http:// groups.yahoo.com/groups/Naija-news/message/25I7. Accessed September 2I, 20I3.

Ojeifo, Sufuyan and Lemmy Ughegbe. 200I. "No Regrets for the Asaba Massacre of Igbo". http://www.nigeriamasterweb.com.

Ohadike, Don C.I994. Anioma: A Social History of the Western Igbo People. Athens, Ohio: Ohio University Press,

Ojukwu, Odumegwu C. I969. Biafra: Selected Speeches with Journal of Events. New York: Harper and Row. 
Okafor,Stanley I. 2002. “The Nigerian Civil War and the 'Liberation' of Asaba: A Personal View." In The Nigerian Civil War and its Aftermath, edited by Eghosa E. Osaghae, Ebere Onwudiwe and Rotimi T. Suberu, 293-300. Ibadan: John Archers Publishers Limited.

Okocha, Emma. 20I2. Blood on the Niger: The First Black-On-Black Genocide. New York: Gomslam Books.

Okonji, B. U. 2006. "A Brief History of St. Patrick's College, Asaba, Nigeria.” In St Patrick's College, Asaba Old Boys' Association of Nigeria Io ${ }^{\text {th }}$ Biennial Convention Brochure, 25-29.

Igbo Youth Congress (I.Y.C.). 2000. Report of the Justice G.C.M. Onyiuke Tribunal, Massacre of Ndigbo in 1966. Ikeja, Nigeria: Tollbrook.

Republic of Biafra. I967.Proclamation of the Republic of Biafra. Enugu, Nigeria: Government Printer.

Soyinka, Wole. I990 edn. The Man Died Ibadan, Nigeria: Spectrum Books.

Talbot, P. A. I969 edn. Peoples of Southern Nigeria(4 Volumes). London: Frank Cass.

TheGuardian on Sunday (Nigeria).2013. "I Have Forgiven All."August II. Vanguard (Nigeria). Wednesday, October Io, 200I.

\begin{abstract}
The Nigerian Civil War was fought between July 30 I967 and January I2, I970. It claimed the lives of over two thousand non-combatants through the hand of soldiers in Aniomaland, an area of the Midwest dominated by Igbo-speaking groups. It was separated by the Niger River from Eastern Igboland and it was not part of the Biafra region. In reconstructing that experience by employing oral sources, this piece expects to seal an observed gap on how the activities of both forces in Aniomaland have been portrayed in history. It also adds to the discussion of who did what in Aniomaland and the impact of those incidents not just on the locals, but on humanity at large. It speaks loud about the atrocities of soldiers in conflicts. Through a micro study, it highlights the rotten possibilities of rabid ethnocentrism and the injuries it can inflict on cherished human values.
\end{abstract}

\title{
Keywords
}

Nigeria; Biafra; War; Massacre; Civilians; Aniomaland. 